\title{
Endovascular treatment of peripheral and visceral arterial injuries in patients with acute trauma
}

\author{
Aysun Erbahçeci Salık, M.D., ${ }^{1}$ Filiz Saçan İslim, M.D., ${ }^{1}$ Barbaros Erhan Çil, M.D. ${ }^{2}$ \\ ${ }^{1}$ Department of Radiology, Bakirköy Dr. Sadi Konuk Training and Research Hospital, İstanbul-Turkey \\ ${ }^{2}$ Department of Radiology, Hacettepe University School of Medicine, Ankara-Turkey
}

\begin{abstract}
BACKGROUND: The present study is an evaluation of the efficacy of endovascular treatment in emergency setting for patients with acute peripheral and visceral arterial injury secondary to penetrating or blunt trauma.

METHODS: Twelve patients (I I men) aged 35.8 I I .3 years (range: I8-56 years) with penetrating or blunt trauma who underwent endovascular treatment in our department between March 2010 and June 2014 for peripheral and visceral arterial injury were retrospectively reviewed. Selective coil embolization was performed on II patients and particle embolization of the injured vessel was performed on I patient. Criteria for endovascular treatment included active extravasation or pseudoaneurysm on contrast-enhanced computed tomography and decrease in hemoglobin level or temporary hemodynamic instability.
\end{abstract}

RESULTS: Arterial injuries were secondary to penetrating injury due to gunshot wound in 4 patients and stab wound in 5, and blunt abdominal injury as result of traffic accident in 3 patients. Traumatic lesions were in the right hepatic artery $(n=3)$, left hepatic $(n=2)$, right hepatic and right renal $(n=I)$, left inferior epigastric $(n=2)$, left facial $(n=I)$, anterior tibial $(n=I)$, and deep femoral $(n=I)$ arteries. Technical success with no procedural complications was seen in all cases. Two patients died due to coexisting injuries on $29^{\text {th }}$ and $43^{\text {rd }}$ days of hospitalization. Median hospitalization period was 6.0 days (range: I-43 days) and mean intensive care unit hospitalization was 7.7 days (range: $0-43$ days).

CONCLUSION: In our experience, endovascular treatment was a safe and effective option for acute traumatic peripheral and visceral arterial lesions.

Keywords: Arterial injury; embolization; endovascular treatment.

\section{INTRODUCTION}

Interventional radiologists play an increasingly important role in the initial stabilization and management of acutely injured trauma patients. ${ }^{[1]}$ Successful use of embolization has been described in all areas of the body following vascular injury. [2,3] Percutaneous transcatheter embolization (TCE) of injured arteries has become a valuable treatment option in management of trauma patients. ${ }^{[4]}$ Selective arterial embolization can stop arterial hemorrhage, often avoiding the need for surgery, or it can establish hemodynamic stability in the presence of other injuries requiring open operation. ${ }^{[2]}$

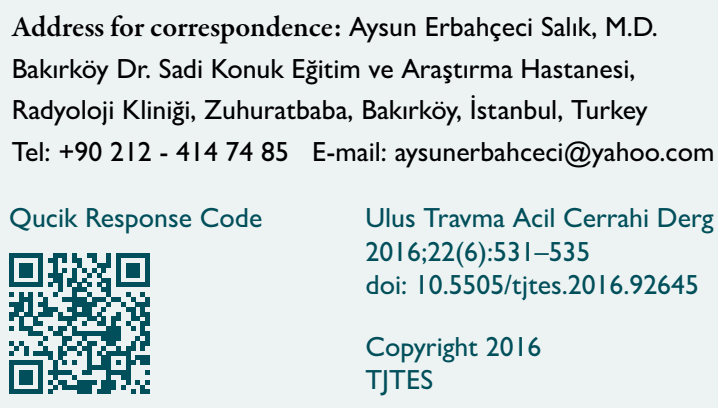

Over the last 2 decades, there has been a paradigm shift in management of solid visceral organ injuries toward non-operative management, and transarterial embolization now has a recognized role in the non-operative management of these injuries. ${ }^{[5]}$ Mortality rate in surgery for blunt hepatic trauma has been reported to be $33 \%$ or greater. $^{[5,6]}$ Effectiveness of TCE for vascular liver injury has been well established, with success rates ranging from $85 \%$ to $100 \% .^{[6-10]}$

The present study is an evaluation of the efficacy of endovascular treatment in emergency setting for patients with acute peripheral and visceral arterial injury secondary to penetrating or blunt trauma.

\section{MATERIALS AND METHODS}

\section{Patient Population}

This is a retrospective analysis of patients with peripheral and visceral arterial injury due to penetrating or blunt trauma who underwent endovascular treatment at our department between March 2010 and June 2014. During this period, 12 
patients (I I men) with mean age of $35.8 \pm$ I I.3 years (range: 18-56 years) were treated.

All patients had documented clinical signs of hemorrhage except I patient who was victim of knife assault and was treated for facial artery pseudoaneurysm (Fig. I). Patients were defined as hemodynamically stable if they were euvolemic with normal clinical and laboratory parameters, and hemodynamically unstable if they were hypovolemic (systolic blood pressure $<80 \mathrm{mmHg}$ with tachycardia) with worsening clinical and laboratory parameters. Patients who were hemodynamically unstable after initial resuscitation were transported directly to operating room for exploration. Hemodynamically stable patients were treated with TCE. Blood transfusions were required for all patients except the patient with fascial artery pseudoaneurysm.

Diagnosis was established for all patients with contrastenhanced computed tomography (CT) or CT angiography (CTA). Presence of active arterial extravasation and pseudoaneurysm formation on CT were accepted as indication for digital subtraction angiography (DSA). Arterial extravasation is identified by focus or area of high attenuation that does not conform to normal vascular structure and is isodense to arterial contrast on arterial phase CT image, which may be contained, as in the case of pseudoaneurysm, or uncontained with free spill.

\section{Endovascular Procedures}

All procedures were carried out in fully equipped angio suite with the patient under general anesthesia or deep sedation. Procedures were performed with fluoroscopic control (Allura Xper FD 20/20, Koninklijke Philips N.V., Amsterdam, Netherlands).

Arterial access was obtained via right or left common femoral artery using standard Seldinger technique. A 4-6 F introducer sheath was placed in the femoral artery, and 4-5 F diagnostic catheters (Cordis Corp., Zug, Switzerland) were placed in the aorta to obtain non-selective diagnostic arteriogram. Diagnostic catheter maneuvers were performed with 0.035 inch guidewire. For extremity lesions, contralateral femoral artery approach was used, and 6 F Destination long introducer sheaths (Terumo Medical Corp., Somerset, NJ, USA) were positioned. When needed, microcatheters (Rebar-I8; Micro Therapeutics, Inc., Irvine, CA, USA and Progreat 2.7 F; Terumo Medical Corp., Somerset, NJ, USA) were used for superselective catheterization. Injured vessels were embolized as distally as possible and pseudoaneurysms were embolized proximally as well as distally, the so-called "closing the front and back door" technique. All lesions were embolized with metallic coils with exception of I patient with liver injury for whom microspheres were used for particle embolization.

\section{RESULTS}

Traumatic lesions were located in the right hepatic $(n=3)$, left hepatic $(n=2)$, right hepatic and right renal $(n=1)$, left inferior epigastric $(n=2)$, left facial $(n=1)$, anterior tibial $(n=1)$, and deep femoral $(n=l)$ arteries. Mechanisms of arterial injuries were secondary to penetrating injury due to gunshot wound in $4(33.3 \%)$ patients and stab wound in $5(41.7 \%)$ patients, and blunt abdominal injury due to traffic accident in 3 (25\%) patients.

Arterial injuries were confirmed by CT scan in all cases. CT scan demonstrated pseudoaneurysms in 4 patients at anterior tibial, deep femoral (Fig. 2), left hepatic, or facial arteries. In the remaining 8 patients, active extravasation was detected on CT examination.

Six patients presented with hemodynamic instability, and 3 patients responded to initial resuscitation. Three patients did not respond to initial resuscitation in the emergency department
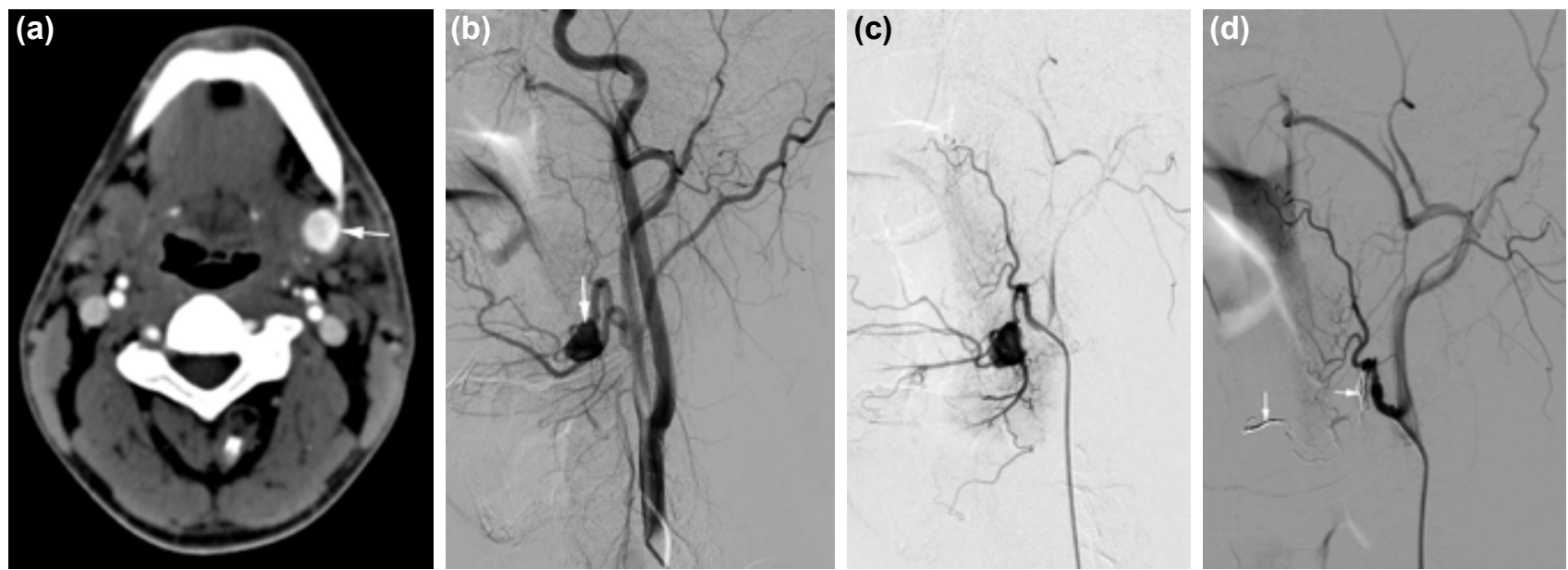

Figure 1. A 33-year-old male with a stab wound to the neck. (a) CT scan revealed a pseudoaneurysm at fascial artery; (b) Pseudoaneurysm was seen on angiography and (c) the injured branch was superselectively catheterized; (d) Pseudoaneurysm was embolized proximally and distally (arrows) with detachable coils and the pseudoaneurysm was no longer filling. 
and were transported to operating room for exploration and compression. After operative packing of liver in 2 patients, and surgical exploration and compression of pelvis in I patient, hemodynamic status of patients were stabilized; however, hemoglobin levels continued to decrease. CTA was performed on these patients and vascular injuries were localized.
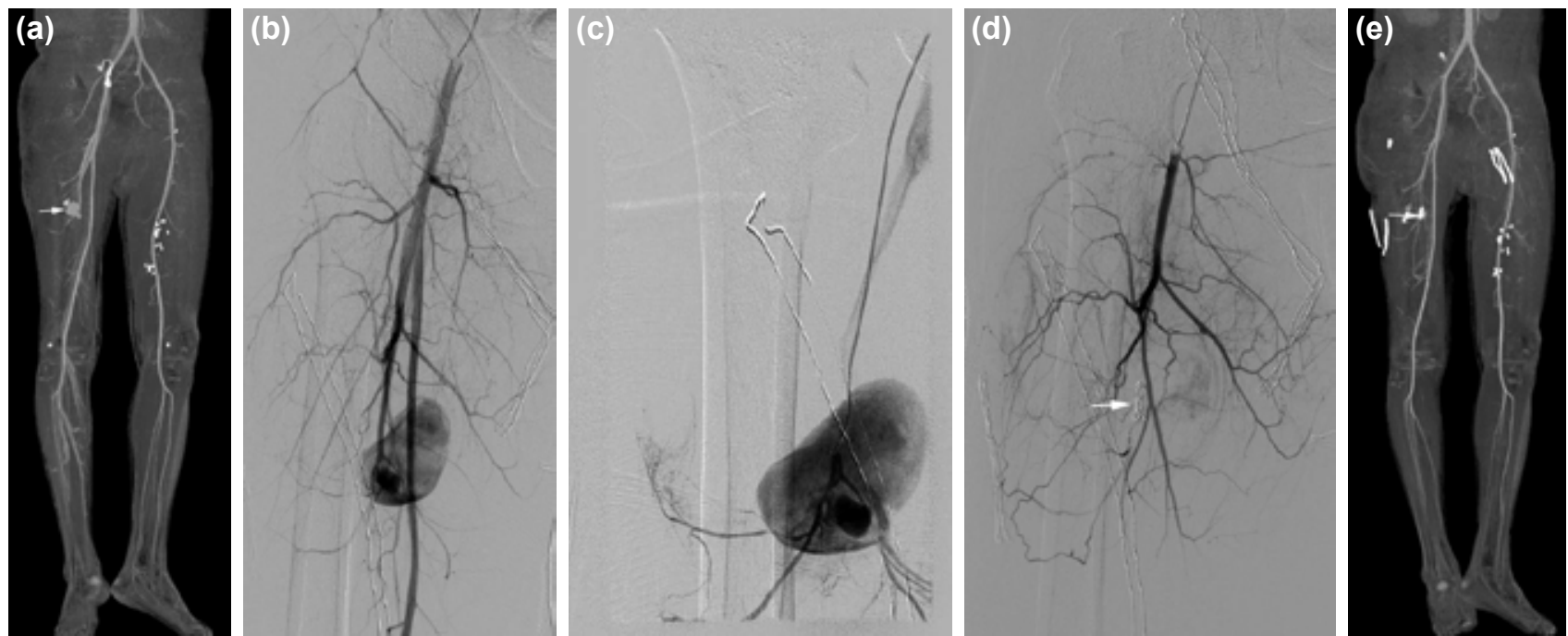

Figure 2. A 33-year-old male presented with a pulsatile mass in the right thigh due to a stab wound. (a) Computed tomography angiography image revealed a pseudoaneurysm and arteriovenous fistula at right deep femoral artery; (b, c) Arteriography confirmed the diagnosis and (d) completion angiography after treatment with pushable coils showed full embolization of the pseudoaneurysm; (e) Computed tomography angiography image after embolization confirmed complete embolization of the pseudoaneurysm.
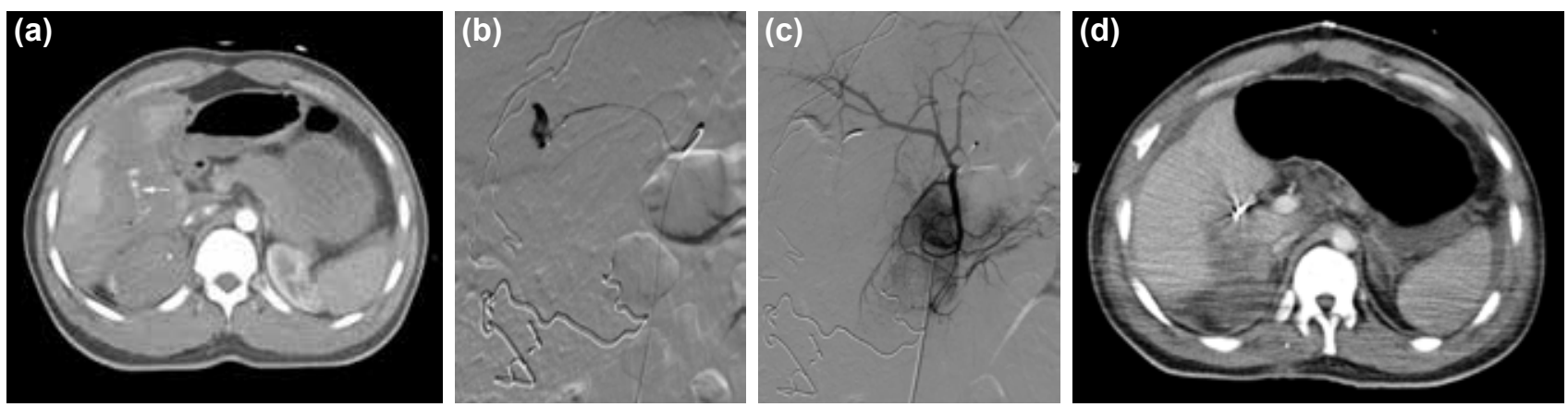

Figure 3. A 23-year-old male with grade IV liver injury due to a gunshot wound. (a) Contrast-enhanced computed tomography in the arterial phase revealed active arterial bleeding with contrast extravasation; (b) Superselective angiography confirmed active arterial extravasation; (c) Completion angiography after embolization with detachable coils showed successful control of the hemorrhage; (d) Successful control of the extravasation was seen on computed tomography angiography image 7 days after the embolization procedure.
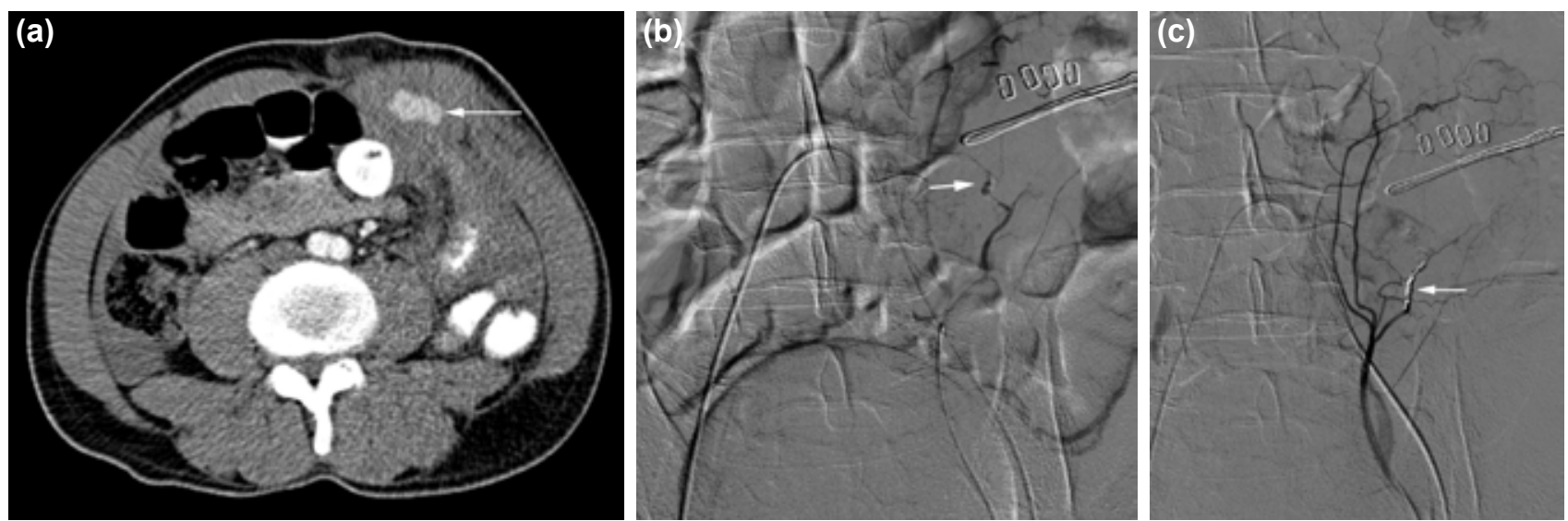

Figure 4. A 42-year-old male with a stab wound. (a) Contrast-enhanced computed tomography in the arterial phase revealed contrast extravasation in the left inferior epigastric artery; (b) Selective angiography confirmed active arterial bleeding; (c) Completion angiography after embolization with detachable coils revealed complete embolization. 
Six hemodynamically stable patients underwent TCE following CT examination and technical success rate was $100 \%$ (Figs. 3, 4). Pushable $(n=5)$ and detachable $(n=6)$ coils were used in II cases, and spherical particles were used as embolic agent in procedure for patient with high-grade liver injury. Particles were preferred due to presence of widespread multiple arterial injuries in lacerated liver parenchyma. There was no procedure-related mortality, or complications. Two patients died due to coexisting injuries on $29^{\text {th }}$ and $43^{\text {rd }}$ days of hospitalization. Outcomes were assessed by clinical examination, CT, and Doppler ultrasonography. Median hospitalization period was 6.0 days (range: $\mathrm{I}-43$ days) and mean intensive care unit hospitalization was 7.7 days (range: $0-43$ ).

\section{DISCUSSION}

In this series, arterial hemorrhage of 12 patients with peripheral and visceral arterial injury due to trauma was treated successfully with TCE. TCE was performed on patients who were hemodynamically stable, or whose hemodynamic status was stabilized with initial resuscitation. Patients who were hemodynamically unstable despite initial resuscitation were directly transported to operating room for exploration. Traditionally, hemodynamically unstable patients have been taken straight to surgery rather than undergo CT or angiography. ${ }^{[2,11]}$ For hemodynamically stable patients, advances in vascular interventional radiology now offer alternative minimally invasive treatment. ${ }^{\left[{ }^{\prime I}\right]}$ There is consensus on operative exploration for hemodynamically unstable patients with suspected high-grade liver injury. ${ }^{[12]}$ However, endovascular treatment option is increasingly selected for some unstable patients. Trellopoulos et al. reported $100 \%$ technical success rate with no procedural complications in endovascular management of peripheral arterial trauma in patients presenting in hemorrhagic shock. ${ }^{[13]}$ Mohan et al. also reported successful results of prompt endovascular treatment in both pediatric and adult patients with hemodynamically compromised hepatic vascular trauma. ${ }^{[7]}$

While surgical exploration has the advantage of directly visualizing an injured blood vessel, it is associated with blood loss and infection. It is also important to remember that a surgeon can only see the outside of a blood vessel and may miss significant damage to arterial intima. In addition, direct exploration risks disturbing a hematoma, which may bleed substantially and might have been self-limiting if left undisturbed. ${ }^{[2]}$ Hepatic arterial hemorrhage in deep liver parenchyma is difficult to control, even with operative packing. Furthermore, surgical exploration to localize exact bleeding point may sometimes be troublesome. Postoperative CT examination and TCE may be useful for patients with persistent hemoglobin level decrease.

All of our patients were treated with TCE as result of indications confirmed by CT. Multislice CT is the best imaging study for evaluation of stable trauma patients. ${ }^{[5]}$ Primary screening of hemorrhagic trauma patients with rapid early-phase $C T$ has been shown to be useful to determine subsequent angiographic intervention. ${ }^{[13]} \mathrm{A}$ prospective multicenter trial using contrast-enhanced helical CT to evaluate stable patients found that $18.4 \%$ of patients with visceral injuries had arterial extravasation, and patients with arterial extravasation were significantly more likely to undergo TCE or surgery. ${ }^{[14]}$

We preferred to use coils as embolic agent for the procedures in this study. The choice of embolic agent will vary based on the site and nature of the injury, the desire to preserve collateral flow, and operator experience. Gelfoam (Pfizer, Inc., NY, NY, USA), particles, glue, and coils are the most commonly selected embolic agents in trauma. ${ }^{[2,5]}$ In emergency situation, coils are often the fastest agent to deploy and can be delivered with considerable accuracy. ${ }^{[5]}$

Quick diagnosis and prompt TCE can be life-saving for patients with hemorrhagic trauma. Furthermore, endovascular treatment options may avoid need for surgery, which has high mortality and morbidity rates in emergency setting. With technological improvements in the last decades, minimally invasive techniques have become alternative treatment option for acutely injured patients. In conclusion, TCE is technically feasible and effective for trauma patients with acute arterial hemorrhage.

\section{Conflict of interest: None declared.}

\section{REFERENCES}

1. Glorsky SL, Wonderlich DA, Goei AD. Evaluation and management of the trauma patient for the interventional radiologist. Semin Intervent Radiol 2010;27:29-37. Crossref

2. Nicholson AA. Vascular radiology in trauma. Cardiovasc Intervent Radiol 2004;27:105-20. Crossref

3. Rich NM, Rhee P. An historical tour of vascular injury management: from its inception to the new millennium. Surg Clin North Am 2001;81:1199-215. Crossref

4. Müller-Wille R, Heiss P, Herold T, Jung EM, Schreyer AG, Hamer OW, et al. Endovascular treatment of acute arterial hemorrhage in trauma patients using ethylene vinyl alcohol copolymer (Onyx). Cardiovasc Intervent Radiol 2012;35:65-75. Crossref

5. Gould JE, Vedantham $S$. The role of interventional radiology in trauma. Semin Intervent Radiol 2006;23:270-8. Crossref

6. Schwartz RA, Teitelbaum GP, Katz MD, Pentecost MJ. Effectiveness of transcatheter embolization in the control of hepatic vascular injuries. J Vasc Interv Radiol 1993;4:359-65. Crossref

7. Mohan B, Bhoday HS, Aslam N, Kaur H, Chhabra S, Sood N, et al. Hepatic vascular injury: clinical profile, endovascular management and outcomes. Indian Heart J 2013;65:59-65. Crossref

8. Ciraulo DL, Luk S, Palter M, Cowell V, Welch J, Cortes V, et al. Selective hepatic arterial embolization of grade IV and V blunt hepatic injuries: an extension of resuscitation in the nonoperative management of traumatic hepatic injuries. J Trauma 1998;45:353-9. Crossref

9. Hagiwara A, Yukioka T, Ohta S, Tokunaga T, Ohta S, Matsuda H, et al. Nonsurgical management of patients with blunt hepatic injury: efficacy of transcatheter arterial embolization. AJR Am J Roentgenol 
1997;169:1151-6. Crossref

10. Mohr AM, Lavery RF, Barone A, Bahramipour P, Magnotti LJ, Osband AJ, et al. Angiographic embolization for liver injuries: low mortality, high morbidity. J Trauma 2003;55:1077-82. Crossref

11. Naidoo NM, Corr PD, Robbs JV, Maharaj J, Nair R. Angiographic embolisation in arterial trauma. Eur J Vasc Endovasc Surg 2000;19:77-81.

12. Kong YL, Zhang HY, He XJ, Zhao G, Liu CL, Xiao M, et al. Angiographic embolization in the treatment of intrahepatic arterial bleeding in patients with blunt abdominal trauma. Hepatobiliary Pancreat Dis Int
2014;13:173-8. Crossref

13. Okamoto K, Norio H, Kaneko N, Sakamoto T, Kaji T, Okada Y. Use of early-phase dynamic spiral computed tomography for the primary screening of multiple trauma. Am J Emerg Med 2002;20:528-34. Crossref

14. Yao DC, Jeffrey RB Jr, Mirvis SE, Weekes A, Federle MP, Kim C, et al. Using contrast-enhanced helical CT to visualize arterial extravasation after blunt abdominal trauma: incidence and organ distribution. AJR Am J Roentgenol 2002;178:17-20. Crossref

\section{ORİJINAL ÇALIŞMA - ÖZET}

\section{Akut travma hastalarında periferik ve viseral arteriyel yaralanmaların endovasküler tedavisi Dr. Aysun Erbahçeci Salık, ${ }^{1}$ Dr. Filiz Saçan Isslim, ${ }^{1}$ Dr. Barbaros Erhan Çil ${ }^{2}$}

${ }^{1}$ Bakırköy Dr. Sadi Konuk Eğitim ve Araştırma Hastanesi, Radyoloji Kliniği, İstanbul

${ }^{2}$ Hacettepe Üniversitesi, Tıp Fakültesi, Radyoloji Kliniği, AnkaraAMAÇ: Bu çalışma, penetran ve künt travmaya bağlı akut periferik ve viseral arteriyel yaralanması olan hastalarda endovasküler tedavinin etkinliğini araştırmayı amaçlamaktadır.

GEREÇ VE YÖNTEM: Mart 2010 ve Haziran 2014 tarihleri arasında, penetran ve künt travmaya bağlı periferik ve viseral arteriyel yaralanma nede-

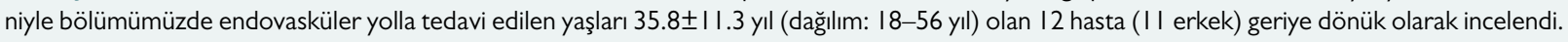
Hastaların I I'inde selektif koil embolizasyonu, birinde partikül embolizasyonu ile yaralanan arterler embolize edildi. Endovasküler tedavi kriterleri; kontrastlı bilgisayarlı tomografide aktif arteriyel ekstravazasyon veya psödoanevrizma ve hemoglobin seviyelerinde düşüş veya geçici hemodinamik instabilite idi.

BULGULAR: Arteriyel yaralanma mekanizmaları dört hastada ateşli silah yaralanması, beş hastada delici kesici alet yaralanmasına bağlı penetran travma ve üç hastada trafik kazasına bağlı künt travma idi. Travmatik lezyonlar sağ hepatik arterde $(n=3)$, sol hepatik $(n=2)$, sağ hepatik ve sağ renal $(n=1)$, sol inferior epigastrik $(n=2)$, sol fasiyal $(n=1)$, anteriyor tibial $(n=1)$ ve derin femoral $(n=I)$ arterlerde yer almaktaydı. Tüm olgular işleme bağlı komplikasyon olmaksızın teknik başarı ile tedavi edildi. İki hasta hastane yatışlarının 29. ve 43. günlerinde eşlik eden yaralanmaları nedeniyle kaybedildi. Ortanca hastane yatış süresi altı gün ( I-43 gün) ve ortalama yoğun bakım yatış süresi ise 7.7 (0-43 gün) gündü.

TARTIŞMA: Bizim deneyimlerimize göre endovasküler tedavi akut periferik ve viseral arteriyel yaralanmaların tedavisinde etkili ve güvenli bir seçenektir.

Anahtar sözcükler: Arteriyel yaralanma, embolizasyon; endovasküler tedavi.

Ulus Travma Acil Cerrahi Derg 2016;22(6):531-535 doi: 10.5505/tjtes.2016.92645 